\section{Neurotoxicology in need of a fix}

\section{Washington}

US research into the neurotoxic effects of hazardous chemicals is fragmented and inadequate, concludes a report released last week by Congress's research body, the Office of Technology Assessment (OTA). As a result, illness stemming from exposure to neurotoxic substances may often go undetected.

Among the options the report offers are substantial increases in support for research and screening of potentially harmful compounds, increased support for neurotoxicology training programmes and a fiveyear plan to boost the impact of research supported by the National Institutes of Health (NIH).

OTA found the programmes currently carried out under the auspices of NIH, the Environmental Protection Agency and the Alcohol, Drug Abuse, and Mental Health Administration to be of "insufficient size and scope" to address the full problem of environmental neurotoxins. The report stresses that EPA's intramural neurotoxicology programme has been hampered by lack of funding. Despite the need for effective in vitro neurotoxicity tests that will minimize the use of animals, EPA recently had a request for extra funds to develop such tests turned down by a government budget office.

The new report emerges against a background of increasing concern over the neurological effects of chemicals. In a series of influential studies, William Langston and colleagues at California Parkinson's Foundation found that MPTP, a chemical created as by-product during the illicit manufacture of synthetic heroin, can induce the symptoms of Parkinson's disease. MPTP's development as a herbicide had previously been halted only by the emergence of more effective chemicals. Langston now believes that the "preponderance of the evidence" indicates that Parkinson's disease is largely caused by non-genetic factors, although others still think there may be a significant hereditary contribution.

Also mentioned in the OTA report is evidence suggesting that a recent increase in the incidence of motor neuron disease, primarily amyotrophic lateral sclerosis (ALS), in the United States is due to environmental agents. But establishing the identities and biochemical effects of the causative agents is likely to prove difficult. The report claims that differences in scientific judgement on the general role of environmental factors in diseases such as ALS and Alzheimer's disease, as well as the parts played by particular causative agents in the progress of neurological diseases, hamper the coordination of federal research and regulatory programmes.

David Concar

\title{
Gore weathers storm
}

\section{Washington}

THE latest in a series of sporadic legal wrangles over the true identity of GoreTex - a stretched form of the low-friction plastic Teflon which is widely used in outdoor clothing as well as such things as space suits and artificial arteries - has ended with the US company that discovered the material coming unstuck over a vaguely worded patent and evidence of an earlier discovery in Japan.

The company, Maryland-based Gore Associates Ltd, has long weathered legal storms over Gore-Tex, but last week showed signs of losing its grip on the material when a US federal court in Phoenix rejected the company's claims of patent infringement by Impra, a medical prosthetics company in Tennessee. Judge Charles Hardy, ruled that Gore's patent specifications failed to define a unique material and so offered no protection.

Gore-Tex was discovered serendipitously by Robert Gore in 1969 when in stretching a rod of polytetrafluorethylene (PTFE) - the plastic from which Teflon is made - he inadvertently gave it a sharp tug rather than a slow pull. The resulting material was an expanded form of PTFE that combined the chemical inertness and low-friction properties of Teflon with high tensile strength and permeability.

What began as a small basement business is now an international concern with a reputed turnover of more than $\$ 700$ million. Yet Gore's success belies a host of patent problems. It took three failed applications and a delay of ten years before the company succeeded in obtaining a US patent in 1979. And in 1984, the company came close to losing that patent in a suit against a New York company called Garlock Inc. Throughout its patent wrangles, Gore has been dogged by questions about an earlier Japanese patent issued to Sumitomo Electric Industries Ltd in 1967. In 1984, Garlock Inc. tried but failed to convince an appeals judge that the materials specified by the Japanese and Gore patents were indistinguishable, and that the later Gore patent was therefore invalid.

Gerald North, Impra's attorney and a veteran of the 1984 dispute, believes that one reason why Impra has succeeded where Garlock failed was that Impra commissioned a team of distinguished materials scientists - led by Edward Clark of the University of Tennessee who pioneered the early studies of PTFE in the 1950 's - to make the Japanese material, following the patent specifications down to the last detail. The result, says North, was a plastic which, when tested according to Gore's own protocol, proved indistinguishable from Gore-Tex.

Gore's attorney, Iain Campbell, however, maintains that the prior Japanese patent is "hopelessly vague" and that it was only with the "hindsight" afforded by the later Gore patent that Impra's scientists were able to use it as a recipe for Gore-Tex.

A second factor crucial to Impra's victory was the judge's ruling that Gore's patent fails to define which of several possible tests should be used to characterize the material's tensile properties. "Gore had provided in effect no way to determine whether infringement had or had not occurred in a particular case", says North. But Campbell argues that the ruling on tensile strength tests reflects a "wooden interpretation" of the patent and that it would be obvious to an expert which of the tests should be used.

Gore-Tex intends to challenge the ruling in the Courts of Appeal. And according to Campbell, if the ruling is upheld on appeal it could have general implications for the way in which patents for new materials are written in the future.

David Concar

ARIANE

\section{Back up by August}

Paris

THE European commercial space rocket, Ariane, should resume launches at the end of July or the beginning of August, according to Frédéric d'Allest, the director of Arianespace. Launches were stopped pending an inquiry after the last launch, flight 36 , ended in an explosion a few minutes after lift-off. As the cause of the explosion was a discarded rag blocking cooling circuits, safety checks have been stepped up, but the design of Ariane rockets has not needed to be revised.

Customer confidence in the launcher has evidently not been shaken either - six new contracts have been signed since the explosion. The next launch will carry the French direct-broadcasting television satellite, TDF-2, and DFS-2 Kopernikus, a West German telecommunications satellite.

Peter Coles

\section{FAST-BREEDER REACTORS}

\section{Superphénix encore}

Paris

THE French fast-breeder reactor, Superphénix has developed a new leak in its liquid sodium cooling system. At fault is a junction in heat-exchange circuitry, and about $\mathbf{1 0}$ litres of coolant are said to have been lost during the night of 27 April.

The reactor has been shut down while tests are carried out for other cracks and is expected to restart in June. The reactor, for whose closure neighbouring Swiss residents have been campaigning for several years, developed a serious leak in 1987 and was out of service for two years.

Peter Coles 